\title{
土工搬土計画改善に関する研究 STUDY ON IMPROVEMENT OF HAULING PLAN FOR EARTH MOVING
}

\author{
石川 六 郎* \\ By Rokuro ISHIKAWA
}

\section{1.はじめに}

土工は土地造成工事の基本となる作業である。とりわ け土工の成否に大きな影響を及ぼすのは，切盛土工の効 率を決定する搬土計画の巧拙である。

従来の搬土計画は, 道路工事のように線状に伸びた工 事を主な対象とし，マスカーブ (土積曲線)を利用した 手法で立案されてきた。しかし, 最近の土地造成工事の ように地形が複雑, 急峻となり, 切盛土量のアンバラン スが顕著になると従来のマスカーブ手法では施工の実態 に即した合理的計画の立案が困難になっている。さら に, ニュータウン計画のように工事規模が大きくなる と, 土工単価のわずかな差が総金額の大きな差となるた め, より精密な検討が要求されている。

本研究では，このように面的な広がりのある工事場所 における搬土計画を合理的に立案する方法を考察する。 さらに，電子計算機を利用することにより施工管理のた めの適切な資料を提供する方法についても考察する。

\section{2. 搬土計画最適化の考え方}

\section{(1) 搬土計画の最適化}

従来の施工計画では (運搬上量 $) \times($ 運搬距離 $)=($ 運搬 作業量）を最小にすることを目標にして決められた距離 ランク別の運搬土量をみながら, 過去の経験に基づき適 当な機種を割り付けていた。しかし，このような方法に は次の欠点がある。

(1) 平面上での最短搬路を決めても現実には途中の池 や保存林等の障害物のために, 重機の通行が不可能であ ったり，あるいは地表面勾配が急峻で予定していた重機 では通行不可能か，もしくは著しく性能が低下寸る場合

* 正会員 (株) 鹿島建設 副社長
がある。

(2) 最適重機の機種選定基準を水平距離においている が，搬路地形を考えた場合には必ずしも妥当な仮定では なく，したがって得られた結果が最適であるとはいえな い場合も考えられる。

(3) 運搬距離, 搬路勾配, 土質条件などが相互に関連 してとりあげられていないので施工の実態からかけ離れ る恐れがある。

本研究では, このような欠点を補うため各機種ごとに 運搬距離，搬路勾配，土質条件を与えて，その搬路をと る場合の土工単価を直接求め, 次式で示される目的関数 を最小にするような運搬経路と土量, 使用重機機種等の 選定方法を検討する。

$$
(\text { 総土工費 })=(\text { 運搬土量 }) \times(\text { 土工単価 })
$$

\section{（2）定式化と解法の整理}

\section{a) ブロック分割}

工事区域の切盛作業を行ら範囲を網目状（メッシュ） に区分して，各メッシュごとに切土量および盛土量を別 々に求め, これと各メッシュの重心位置での現地盤高, 計画高を基本データとする (図一1 参照)。

このメッシュから搬出または搬入される土量は，その メッシュ内で切盛を相殺させたときの差量として求め る。なお, 以後の計算処理を簡略化するため, 切土また は盛土のみのメッシュを適当な大きさのブロックにまと めることもできるようにする。土砂は切土のブロックか ら盛土のブロックへ運ばれるものとし，そのブロック間 距離が運搬距離となる。運搬経路の途中に池や急斜面な どの障害のない場合は, 両ブロックの重心間距離をもっ て運搬距離とする。すなわち $i$ 番地の切土ブロックから $j$ 番地の盛土ブロックまでの運搬距離 $d_{i j}$ は次式で与え られる。

$$
\left.\begin{array}{c}
d_{i j}=\text { ブロック } i \text { とブロック } j \text { との重心 } \\
\text { 間距離（障害のない場合） }
\end{array}\right\}
$$




\begin{tabular}{|c|c|c|c|c|c|c|c|c|c|c|c|c|}
\hline & & & & & 1044 & $\begin{array}{r}786 \\
1559\end{array}$ & $\begin{array}{l}501 \\
955\end{array}$ & & & & & \\
\hline & & & $44 / 3$ & $\begin{array}{r}191 \\
1701\end{array}$ & $\begin{array}{r}9 \\
1224 \Omega\end{array}$ & 11870 & $\begin{array}{l}1391 \\
3393\end{array}$ & $\begin{array}{r}5047 \\
524\end{array}$ & $\begin{array}{l}719 \\
806\end{array}$ & 735 & & \\
\hline & & & 16112 & $\begin{array}{l}3782 \\
3982\end{array}$ & 16517 & 18710 & $\begin{array}{r}34 \\
10224\end{array}$ & $\begin{array}{r}102 \\
7732\end{array}$ & $\begin{array}{r}51 \\
6709\end{array}$ & $\begin{array}{r}707 \\
16\end{array}$ & & \\
\hline & & 4223 & 22720 & $\begin{array}{r}13254 \\
186\end{array}$ & $\begin{array}{l}4382 \\
1839\end{array}$ & $\begin{array}{c}786 \\
7748\end{array}$ & 21827 & 17800 & $\begin{array}{r}792 \\
5307\end{array}$ & $\begin{array}{r}3293 \\
18\end{array}$ & & \\
\hline & $\begin{array}{r}15 \\
2389\end{array}$ & $\begin{array}{r}79 \\
281\end{array}$ & 24370 & 19252 & $\begin{array}{r}7438 \\
146\end{array}$ & $\begin{array}{r}885 \\
6213\end{array}$ & 19440 & $\begin{array}{r}206 \\
6804\end{array}$ & $\begin{array}{r}6252 \\
359\end{array}$ & 11127 & 427 & \\
\hline & $\begin{array}{r}216 \\
9556\end{array}$ & $\begin{array}{r}876 \\
2754\end{array}$ & 21382 & 17357 & $\begin{array}{r}830 \\
6350\end{array}$ & $\begin{array}{r}88 \\
1: 398\end{array}$ & $\begin{array}{r}12 \\
16884\end{array}$ & 12622 & $\begin{array}{r}5036 \\
566\end{array}$ & 12392 & 947 & \\
\hline 1853 & $\begin{array}{l}1665 \\
6 \dot{9} 20\end{array}$ & $\begin{array}{r}483 \\
9755\end{array}$ & $\begin{array}{r}10627 \\
40\end{array}$ & 13455 & $\begin{array}{r}9194 \\
696\end{array}$ & $\begin{array}{r}4540 \\
380\end{array}$ & $\begin{array}{r}158 \\
10950\end{array}$ & 17522 & $\begin{array}{l}2016 \\
3201\end{array}$ & $\begin{array}{l}5064 \\
1097\end{array}$ & 4517 & \\
\hline 1326 & $\begin{array}{r}6767 \\
125\end{array}$ & $\begin{array}{r}192 \\
11704\end{array}$ & $\begin{array}{l}1536 \\
4410\end{array}$ & $\begin{array}{l}2809 \\
1186\end{array}$ & 15412 & $\begin{array}{l}4922 \\
1302\end{array}$ & 10920 & 19265 & 13380 & $\begin{array}{r}498 \\
8228\end{array}$ & $\begin{array}{r}6800 \\
252\end{array}$ & $\begin{array}{r}996 \\
87\end{array}$ \\
\hline & $\begin{array}{r}5872 \\
3\end{array}$ & $\begin{array}{l}3906 \\
2701\end{array}$ & 11460 & $\begin{array}{r}66 \\
8823\end{array}$ & $\begin{array}{r}9764 \\
109\end{array}$ & 15552 & $\begin{array}{r}807 \\
5187\end{array}$ & 18032 & 12755 & $\begin{array}{r}7820 . \\
442\end{array}$ & 17415 & $\begin{array}{r}1873 \\
2\end{array}$ \\
\hline & $\begin{array}{r}5155 \\
78\end{array}$ & $\begin{array}{r}6331 \\
22\end{array}$ & $\begin{array}{l}2441 \\
3951\end{array}$ & $\begin{array}{r}47 \\
8580\end{array}$ & $\begin{array}{l}4835 \\
1252\end{array}$ & 13312 & $\begin{array}{l}5906 \\
2251 \\
\end{array}$ & $\begin{array}{l}1044 \\
7437\end{array}$ & 1397 & $\begin{array}{r}3560 \\
877\end{array}$ & 14580 & $\begin{array}{r}3425 \\
260\end{array}$ \\
\hline & $\begin{array}{r}5139 \\
208\end{array}$ & 15140 & $\begin{array}{r}8975 \\
88\end{array}$ & $\begin{array}{r}245 \\
5955\end{array}$ & 9310 & $\begin{array}{l}5035 \\
2233\end{array}$ & 14242 & $\begin{array}{l}4256 \\
1846\end{array}$ & 12125 & $\begin{array}{l}1191 \\
2364\end{array}$ & $\begin{array}{r}11157 \\
7\end{array}$ & $\begin{array}{r}9322 \\
41\end{array}$ \\
\hline & $\begin{array}{l}48 \\
12\end{array}$ & $\begin{array}{r}10190 \\
168\end{array}$ & 15550 & $\begin{array}{r}9090 \\
7\end{array}$ & $\begin{array}{l}2443 \\
27.33\end{array}$ & 7247 & $\begin{array}{r}929 \\
3446\end{array}$ & $\begin{array}{l}2588 \\
1863\end{array}$ & 8720 & $\begin{array}{r}17 \\
4017\end{array}$ & $\begin{array}{r}696 \\
18\end{array}$ & $\begin{array}{r}2401 \\
160\end{array}$ \\
\hline & & $\begin{array}{r}2262 \\
44\end{array}$ & $\begin{array}{r}2817 \\
42\end{array}$ & $\begin{array}{r}1778 \\
174\end{array}$ & $\begin{array}{r}1967 \\
84\end{array}$ & $\begin{array}{r}30 \\
6573\end{array}$ & $\begin{array}{l}2060 \\
5517\end{array}$ & $\begin{array}{l}1053 \\
5253\end{array}$ & $\begin{array}{r}16 \\
7341\end{array}$ & 6443 & $\begin{array}{r}2 \\
662 \\
\end{array}$ & $\begin{array}{l}14 \\
80\end{array}$ \\
\hline & & & & & & & 3002 & 3014 & $\begin{array}{r}7505 \\
31\end{array}$ & $\begin{array}{l}2299 \\
1704\end{array}$ & $\begin{array}{r}1 \\
2310\end{array}$ & \\
\hline & & & & & & & & & & $\begin{array}{r}1342 \\
116 \\
\end{array}$ & 743 & \\
\hline 32 & 249 & 437 & 1310 & 819 & 573 & 459 & 290 & 173 & 224 & 500 & 565 & 180 \\
\hline 0 & 193 & 2.14 & 200 & 306 & 513 & $7 b 3$ & 1110 & $116 l$ & 853 & 259 & 40 & 0 \\
\hline 32 & 281 & 717 & 2027 & 2847 & 3420 & 3879 & 4170 & 4343 & 4567 & 5068 & 5633 & 5813 \\
\hline 0 & 193 & 467 & 667. & 973 & $\begin{array}{l}1486 \\
\text { COLUMM }\end{array}$ & $\begin{array}{l}2239 \\
\text { IN TOTAL }\end{array}$ & $\begin{array}{r}3349 \\
\left(100 M^{2}\right)\end{array}$ & 4516 & 5369 & 5629 & 5668 & 5675 \\
\hline
\end{tabular}

(2)

$132 \quad 156$

$208 \quad 305 \quad 364$

$639 \quad 970$

$494 \quad 858$

$\begin{array}{ll}547 & 1518\end{array}$

$701 \quad 1559$

$350 \quad 18 / 4$

$\begin{array}{lll}591 & 2150 & \\ & 601 & \end{array}$

$536 \quad 2686$

$512 \quad 2987$

$\begin{array}{llll}413 & & 3098 & \\ & 709 & & 3696\end{array}$

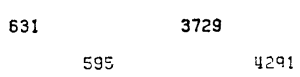

$\begin{array}{llll}606 \quad & 4335 & \\ & 587 & & 4678\end{array}$

$747 \quad 5082$

$440 \quad 5522$

$284 \quad 5303$

$120 \quad 5642$

322

५62G்

5800

5006

5813

3075

図一1 ブロック分割および土工量表示図

$=$ ブロック $i$ とブロック $j$ との最短
迂回距離（障害のある場合）

なお,メッシュの区分のしかた，ブロックへのまとめ 方の程度は使用する電子計算機の容量, 対象とした工事 の地形, 要求される計算の精度, 計算の手間等を勘案し

て決定する。

b) 搬土計画問題の定式化

前述の手順により工事区域が $m$ 個の切土ブロックと $n$ 個の盛土ブロックに分けられたとする。 $i$ 番目の切土 ブロック $(i=1,2, \cdots, m)$ から $j$ 番目の盛土ブロック $(j=1,2, \cdots, n)$ までの運搬土量 $v_{i j}$, 運搬距離 $d_{i j}$, お よび $i, j$ ブロック間の平均勾配 $I_{i j}$ が同様に与えられ
たとする。この作業を重機 $r$ で処理する際の土工単価 $c_{i j}{ }^{r}$ が求められたとすると, この作業の土工費 $z_{i j}{ }^{r}$ は 次式で定義される。

$$
\left.\begin{array}{c}
z_{i j}{ }^{r}=c_{i j}{ }^{r} v_{i j}=f\left(d_{i j}, I_{i j}\right) \cdot v_{i j} \\
\text { こに, } \\
c_{i j}{ }^{r}>0, \quad v_{i j} \geqq 0 \quad(r=1,2, \cdots, l)
\end{array}\right\}
$$

ただし， $l$ は考えている重機機種の数とする。よって,

総土工費 $Z$ は重機 $r$ について次式で与えられる。

$$
\left.\begin{array}{c}
Z=\sum_{i=1}^{m} \sum_{j=1}^{n} z_{i j}{ }^{r}=\sum_{i=1}^{m} \sum_{j=1}^{n} c_{i j}{ }^{r} v_{i j} \\
\text { ここに, } \\
c_{i j}{ }^{r}>0, v_{i j} \geqq 0 \quad(r=1,2, \cdots, l)
\end{array}\right\}
$$

切土ブロック $i$ の切土量を $p_{i}$ とすれば次式が成立す 
る。

$$
\sum_{j=1}^{n} v_{i j}=p_{i} \quad(i=1,2, \cdots, m)
$$

盛土ブロック $j$ の盛土量を $q_{j}$ とすれば次式が成立す る。

$$
\sum_{i=1}^{m} v_{i j}=q_{j}(j=1,2, \cdots, n)
$$

したがって問題は

$$
\begin{aligned}
& \sum_{j=1}^{n} v_{i j}=p_{i}(i=1,2, \cdots, m) \\
& \sum_{i=1}^{m} v_{i j}=q_{j} \quad(j=1,2, \cdots, n) \\
& r=1,2, \cdots, l
\end{aligned}
$$

なる条件のもとで, 目的関数

$$
Z=\sum_{i=1}^{m} \sum_{j=1}^{n} c_{i j}{ }^{r} v_{i j}
$$

を最小とするような $r$ と $v_{i j}$ を決める LP (線型計画) 問題に帰結する。しかし，一般に使用する重機機種は 1 つの現場でせいぜい 3〜4 種類のみなので, それぞれの $v_{i j}$ を決める際にすべての機種についての $c_{i j}$ の值を比 較し， $c_{i j}$ を最小にする機種をとって $v_{i j}$ を決めればよ い。

\section{c） 解法のアルゴリズム}

前項で定式化された LP 型輸送問題を解くには, まず 土工単価を無視して，ある1つの切土ブロックからいく つかの盛土ブロックへ搬土していくといら操作を切盛土 量のバランスする状態まですべての切土（盛土）ブロッ クについて行い (north west corner rule), このとき の組合せによる解 $(m+n-1)$ 個を初期解 $S_{0}$ とする。 $S_{0}$ は土量をバランスさせるといら目的のもとに得られ た解ではあるが，目的関数 $Z$ を最小とする解とは限らな い。そこで解の改善をはかるため次のステップで $S_{0}$ の 切盛土量のバランスの際には考慮しなかったある 1 つの 搬土 $[v]$ をとりあげ，それを解の組の中に新たに加える ことにする。解の組の数は $(m+n-1)$ 個に限定されて いるのでこの新しい $[v]$ を追加すれば， $S_{0}$ のうちから 1つの搬土が除かれることとなり，ここに新しい組合せ の解 $S_{1}$ が求まる。また $S_{0}$ に対する目的関数 $Z$ の值 $Z_{0}$ より $S_{1}$ に対する值 $Z_{1}$ を小にする，すなわち

$$
Z_{0}>Z_{1}
$$

とするために $S_{0}$ を求める際に考慮しなかった般土につ いて式（9）が成立するような $[v]$ を選択することにす る。これを順次行えば

$$
Z_{0}>Z_{1}>Z_{2}>\cdots \cdots
$$

となる。そして, 最終的に

$$
Z_{p}>Z_{p+1}(p \text { は任意の整数 })
$$

なる $[v]$ を選択できなくなった $p$ ステップ目のときに， 目的関数 $Z$ が最小となる。すなわち，そのときの組合
せの解 $S_{p}$ が最適搬土計画を与えるものである。

\section{3. 搬土計画の実際}

\section{(1) 施エステップの分割}

最近の大規模土工工事は丘陵地から山間部へと移りつ つあり，現地盤高と計画地盤高との差が $30 \sim 50 \mathrm{~m}$ ある といら場合もしばしば見られる。このような場合には， 平面上で運搬作業量を求めても意味をなさず, 施工の順 序を考慮し現実の施工に即した計画を作成しなければな らない。すなわち図一2（1）に示すように A ブロック から $\mathrm{C}$ ブロックヘ $a \mathrm{~m}^{3}, \mathrm{~B}$ ブロックから $\mathrm{C}$ ブロック へ $b \mathrm{~m}^{3}$ というように単純に決めるわけにはいかない。 A ブロックの下部の土砂は, B ブロックを切り取った 後でないと運搬できないことは明らかである。そこで, 図一2（2）のように平面的のみならず立体的にステップ 分けを行い，第 1 段階では $\mathrm{A}_{1}, \mathrm{~B}_{1}, \mathrm{C}_{1}$ などについて計 画を立て, 次に第 2 段階では $A_{2}, B_{2}, C_{2}$ などについて 計画を立てるというように順次高低差を考慮した検討を 行ら必要が生じる。

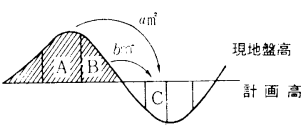

(1I)

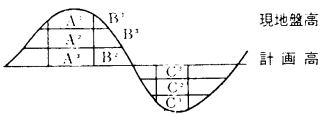

(2)
図一2 施エステップ分割模式図

このように施工順序を勘案して各段階ごとに搬土計画 を立て，現地形を修正しながら次のステップに進むこと により実際の地形上の制約条件, 重機の効率等を考慮し た合理的な施工計画管理が行われるであるう。

\section{（2）ブロック内部調整}

ブロック間の搬土計画を検討するに先立って,ブロッ ク内の切土, 盛土を相殺する。このブロック内部調整に 使用する重機の機種はあらかじめ指定し, 搬土距離は近 似的にブロック辺長の $1 / 2$, 勾配は 0 として処理する。 この土量相殺で余った部分の切土または盛土は, 次のス テップで他ブロックとの間の搬土計画として検討される わけであるが，この際にブロック重心位置での地盤高は 次式で表わされる。

(切土量一盛土量)/ブロック面積

すなわち, 余剩 (不足) 土の平均高さだけ修正された值 を新しい地盤高とする。

\section{（3）使用機種の選定と最適搬路の決定}

a) 土工単価

土工単価は次式で求められる。 


$$
U=C / Q
$$

ただし， $U: 1 \mathrm{~m}^{3}$ 当り土工単価 (円 $/ \mathrm{m}^{3}$ )

$C$ : 重機の 1 時間当り費用 (円/時)

$Q$ : 重機の 1 時間当り作業量 $\left(\mathrm{m}^{3} /\right.$ 時)

また, 重機の 1 時間当り作業量 $Q$ は

$$
Q=60 \cdot q \cdot f_{1} \cdot E / c_{m}
$$

ただし， $q: 1$ サイクル当り作業量 $\left(\mathrm{m}^{3}\right)$

$f_{1}$ : 土量換算係数

$E:$ 作業効率

$c_{m}:$ サイクルタイム（分）

で与えられるので, 上工単価 $U$ は式 (13), (14) から

$$
U=C \cdot c_{m} /\left(60 \cdot q \cdot f_{1} \cdot E\right)
$$

で表わされる。いま，重機としてブルドーザを例にと, て考えると

$$
q=q_{0} \cdot d \cdot \rho
$$

ただし， $q_{0}$ : 初期排土量 $\left(\mathrm{m}^{3}\right)$

\section{$d:$ 押土距離による莪減率}

$\rho:$ 土質の安息角 $(\phi)$ と勾配 $(\alpha)$ によって決 まる倸数

$$
c_{m}=\frac{l}{v_{1}}+\frac{l}{v_{2}}+t_{g}
$$

ただし， $l:$ 押土距離 $(\mathrm{m})$

$v_{1}:$ 前進速度 $(\mathrm{m} /$ 分 $)$

$v_{2}:$ 後退速度 $(\mathrm{m} /$ 分 $)$

$t_{g}:$ ギャ入換え, 加速に要する時間 (分)

であるから，式（15）は

$$
U=C \times\left(\frac{l}{v_{1}}+\frac{l}{v_{2}}+t_{g}\right) /\left(60 \cdot q_{0} \cdot d \cdot \rho \cdot f_{1} \cdot E\right)
$$

となる。

例として, ブルドーザ CAT D 8-46 A について平坦 地の場合の土工単価を搬上距離 $l$ の関数として整理すれ ば, 式 (18) において

$$
\begin{aligned}
& v_{1}=46 \mathrm{~m} / \text { 分（前進 } 1 \text { 速） } \\
& v_{2}=98 \mathrm{~m} / \text { 分（前進 } 2 \text { 速） } \\
& t_{g}=0.33 \text { 分 } \\
& q_{0}=5.13 \mathrm{~m}^{3} \\
& \rho=1.0\left(\phi=30^{\circ}, \alpha=0 \%\right) \\
& f_{1}=1.0 \\
& E=1.0
\end{aligned}
$$

\begin{tabular}{|c|c|c|c|c|c|c|c|c|}
\hline 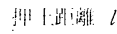 & $10^{m}$ & 20 & 30 & 40 & 50 & (b) & 70 & 80 \\
\hline & 1.00 & 0.96 & 10.92 & 0.88 & (0.84 & 0.80 & 0.76 & $0.7^{2}$ \\
\hline
\end{tabular}

とおくことにより

$$
U_{0}=\frac{0.144 l+1.448}{1.388 d} \cdot C \cdot 10^{-3}
$$

ただし， $d$ : 押土距離によって決まる逓減率

一方，搬路の勾配が $\alpha \%$ である場合の重機作業量は 一般に次式で与えられる。

$$
Q^{\prime}=f(\alpha) \cdot Q
$$

表一1 押土距離に関する係数（ただし $\alpha=0 \%$ の場合）

\section{表一2 勾配に関する係数}

\begin{tabular}{llllllll}
\hline $4 \mathrm{H}_{1} \alpha$ & $15 \%$ & $10 \%$ & $5 \%$ & 0 & $5 \%$ & $10 \%$ & $15 \%$ \\
$f(\alpha)$ & 1.47 & 1.28 & 1.12 & 1.00 & 0.89 & 0.80 & 0.73
\end{tabular}

これまでの経験よりほぼ定められた值となる。たとえ ば, 参考文献 8) によれば, 距離 $l$ と $d$, 勾配 $\alpha$ と $f(\alpha)$ の関係は表一1，2 のように与えられている。

同様な関係を使用予定の全機種についてあらかじめ求 めておく。実際の計算では, 式 (15) で与えられる曲線 をいくつかの区間に分けて直線で近似し

$$
U_{r}=R_{1} \cdot\left(a_{r} \cdot l \cdot R_{2}+b_{r} \cdot R_{3}\right)
$$

なる形に整理しておく。ただし，ここで $U_{r}$ は機種 $r$ (たとえばブルドーザ) について求めた土工単価であり, $a_{r}, b_{r}$ 注使用機種によって決められる定数である。 $R_{1}$, $R_{2}, R_{3}$ は同じ機種の中で重機の性能の差, 搬路勾配お よび土質の差を修正する係数（たとえば CAT D 8-46 A を標準として関係式を求め, これを小松 D-120 A に 修正する場合の係数) を意味している。以上の手続きに より, 現実の種々の要素を考慮した土工単価を算出する ことができる。本論文では運土費用最小を目的関数とし ているが，上述のようにして求められた上工単価を用い て費用の計算を行うことにより，本論文の評価基準に妥 当な信頼性をもたせることができると考える。

\section{b）使用機種と最適搬路}

総土工費を求めるには，各重機についてまず $i, j$ 間 にある $i$ に隣接するブロックへ運搬する場合の土工単価 を式 (21) から求め, $j$ 方向ブロックヘ1 万進み, 次に このブロックを起点とし，これに隣接するブロックにつ いて同様な操作を $j$ ブロックまで行う。この手順により

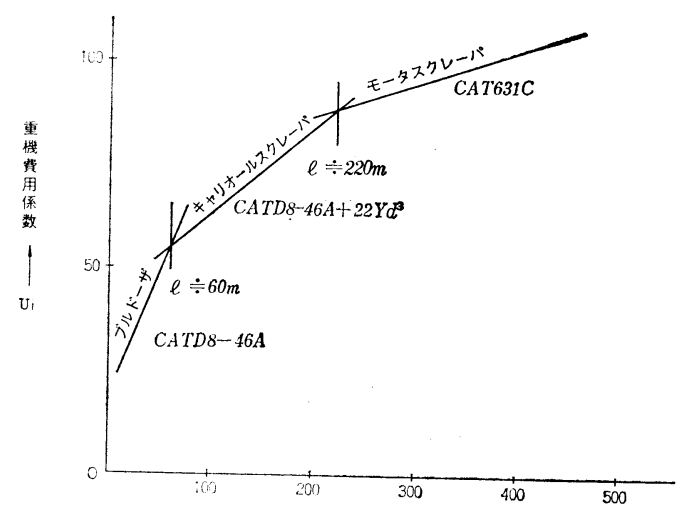

図一3運搬距離と土工単価の関係 
求められた $i$ から $j$ に至る土工単価のトータルが最小 となる経路を最適搬路とする。すなわち機種 $\boldsymbol{r}$ を使用し た場合の最小費用経路が定まる。この結果を，使用可能 な各重機について比較し総土工費を最小にする使用機種 ならびに最適搬路を決定する。機種の違いによる経済性 の比較の一例として，ブルドーザ (CAT D 8-46 A), キャリオールスクレーパ (CAT D 8-46 A + 22Y $\left.d^{3}\right)$, お よびモータスクレーパ (CAT $631 \mathrm{C})$ の 3 機種について 平坦地の場合の距離と土工単価との関係を図一3 に示し た。

この図から，従来は経験的な判断により,ブルドーザ， キャリオールスクレーパ，モータスクレーパなどの機種 選定が行われてきたことに対し, 最小費用といら合理的 な根拠に基づいた機種選定が可能であることがわかる。 しかも，費用計算においては土工単価の算出の際に述心 たように, 運搬距離, 搬路勾配, 土質条件などの種々の 現実的な要素を考慮しているので, 本論文の手法により 得られた図一3のような結果は実際的な意味での信頼性 が高いと判断されよう。

\section{（4）残土，不足土の処理}

計画上，土工量がバランスしておらず残土がある場合 には，前述のように経済的に作業できる部分から搬土計 画が決められるので，もし，何の指定もない場合には残 土，不足土とも最も費用のかかる部分がそのまま残るこ とになる。しかし，事前に場外土取場または土捨場がわ かっている場合には，この土取場または土捨場を 1 つの ブロックとして扱い，運搬距離，搬路勾配を与えること により全体としての最適化を図ることができる。

\section{4. 電子計算機による計算処理}

\section{（1）電子計算機システムの概要}

前章で述べた計算を電子計算機で処理するため, 図一 4 の概略フローチャートに示すようなプログラムを開発 した。このシステムの概要は次のとおりである。

a) インプットデータ

インプットデータはプログラムの初期值設定, 計算処 理方法選択等のためのデータとそのプロジェクト特有の データの 2 種類に大別される。前者はメッシュの寸法, メッシュをブロックへまとめる方法, 工区分割の有無, 何ステップに分けるかのステップ分割の方法, 距離別集 計の際のランク，土層別搬土計画をするかなどの指定デ 一タであり, 後者としては各メッシュごとの切盛土量, 現地盤高, 計画高, 使用重機の機種, 土の体積変化率, 圧密沈下率, 通行禁止地区指定データ, 土工単価計算の

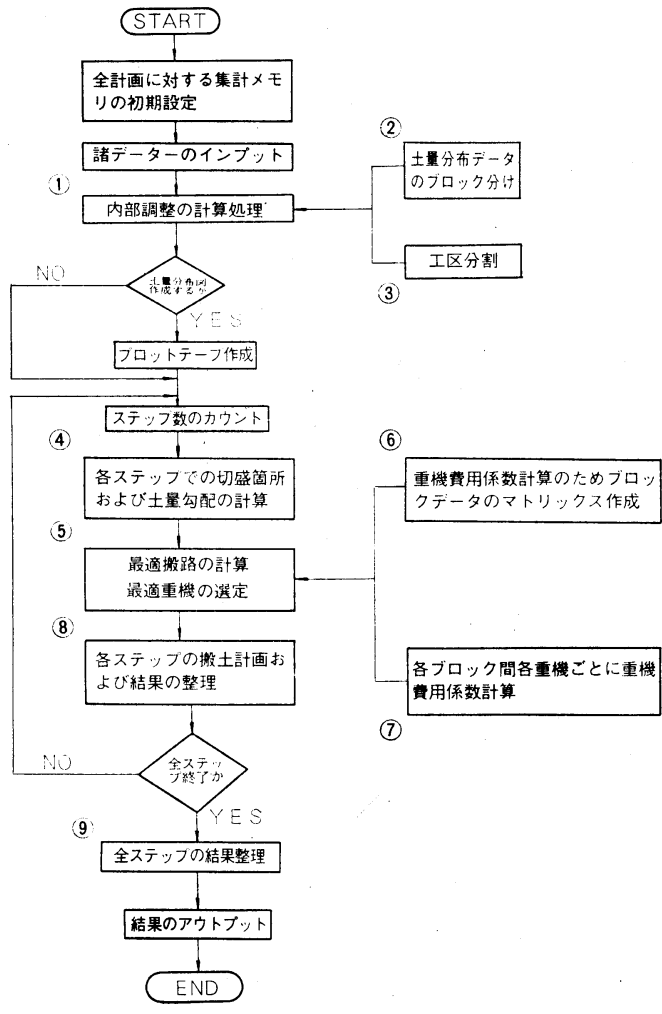

図一4概略フローチャート

ための各機種ごとの修正係数などがある。これらのデー タの中で最も数が多いのは地形, 土量に関するデータで あるが，地形データについては地形が単純な場合または ある規則性をもつ場合にはごくわずかなデータで表示で きるように工夫できる。たとえば，なだらかな丘陵地の 地盤高は平面上の各境界点と曲面で近似寸るための数か 所の高さを与えるだけで全体の丘陵が再現できる。ま た，計画高が段丘のように，ある一定の方向に上下した り勾配あるいは方位について規則性をもつ場合にはデー 夕数がきわめて少なくなる。土工量のバランスに大きな 影響を与える体積変化率, 圧密沈下率は一律に同じデー 夕を与えることはせず, 各ブロック，各ステップごとの 土質の特性，基礎地盤の状況などに合せて指定できる。

b) 計算処理

与えられた地形, 土量データは図一4 の概略フローチ ャートの(2)のパッケージでブロックごとに編集, ファイ ルされ，必要があれば(3のパッケージで切盛がバランス した，いくつかの工区に編集しなおされる。このデータ を使って(1)のパッケージでブロック内の切盛相殺処理を 行い, ブロック間搬土計画のための運搬土量, 地盤高の 変化を計算する。もし必要ならばこの結果を土量分布図 として図示できる。(4)のパッケージではそのステップで の土量分布および各ブロック閒の距離，平均勾配を計算 
する。(6)，(7)のパッケージで各ブロック間の機種ごとの 土工単価を計算し，この結果にもとづき(5)のパッケージ で初期解の改善を図り，このステップでの最適搬路と使 用機種を決定する。得られた結果は(8)のパッケージで機 種ごと, 距離ランクごとに集計, 整理され, 平均運搬距 離の計算を行い，(9のパッケージで各ステップすべての 集計, 整理をして, それぞれの最終結果が得られる。

c) アウトプット

得られる結果は計画の段階のみならず, 施工管理の段 階でも利用できるよう, 指定したステップごとに次の 4 種類のものを表示する。

(1) 各重機ごとの搬土計画 : 切土ブロック番号, 盛土 ブロック番号, 運搬経路, 距離, 土量, 土工単価, 土工量など

(2) 各重機ごとの距離別土量集計表

(3) 切土ブロック番号順に全機種についての搬土計画

(4) 全機種についての距離別土量集計表

すべてのステップが終了した段階で, 総集計として

(1) 各重機ごレの距離別土量集計表

(2) 全機種についての距離別土量集計表

(3) 総土工量上総士工費

が得られる。また, 必要とするステップごとの各ブロッ クの切土量, 盛土量, 運搬経路, 運搬土量をプロッター により図式的に表示し，さらに各ステップごとに工事終 了時の地形図を描かせる。代表的なアウトプットの例と して, ある土地造成工事搬土計画に扔ける第 2 ステップ
の全機種についての搬土計画の一部を表一3に，また 図一5 には表一3 の結果を図に表現したもの, 図一6に 計画前の現地形図, 図一7 に第 2 ステップ終了後の地形 図を示した。

表一3 において, たとえば 12 行目に FROM 20 TO $3, P=294, \quad \operatorname{COST}=144.37, \quad$ DIST $=249.71, \quad J U K I=$ SCRAPER, $P * C=424$, THROUGH $=12,5,1,2$ と あるのは，第 20 ブロックから $12 ， 5 ， 1 ， 2$ の各ブロッ クを経由して第 3 ブロックへ土量 $294 \mathrm{~m}^{3}$ をスクレーパ で運搬し，その際の運搬距離が $249.71 \mathrm{~m}$, 土工単価が 144.37 円 $/ \mathrm{m}^{3}$, この土工費が $424 \times 10^{2}$ 円であることを示 している。得られたアウトプットの中で, まず, 各ステ ップごと, 重機ごとの距離ランク別運搬土量の分布をも とにしてこのステップで投入する重機台数を決定する。 この段階で同一機種の各ステップごとの所要台数が大幅 に異なるような場合には, ステップ分割の数, 方法また は使用機種について再検討が必要である。各ステップ終 了ごとに，その段階での現地形図（たとえば図一7）を 参照しながら次のステップの搬土計画へ地形上の制約条 件を与えることができる。現場での施工管理には, 各ス テップごと，重機ごとの搬土計画とプロッターで描かせ た運搬経路図（たとえば図一5）を併用すれば的確な施 工上の指示を与えることができる。

b) 必要な電子計算機の容量

きめ細かな搬土計画を立てるには, 多数のブロックを 処理する必要があるが, 使用する電子計算機の容量と速

\section{表一3 全機種についての搬土計画}

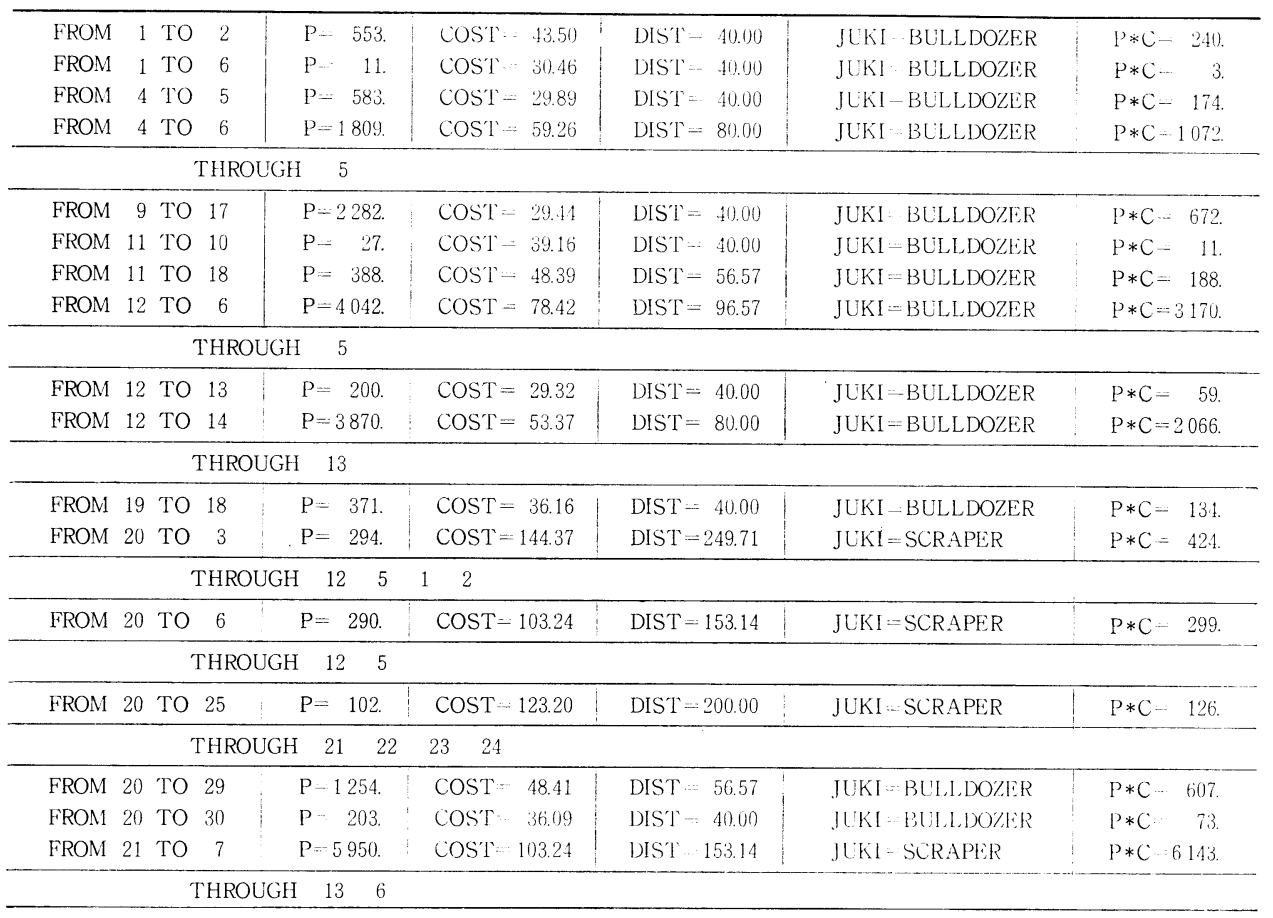




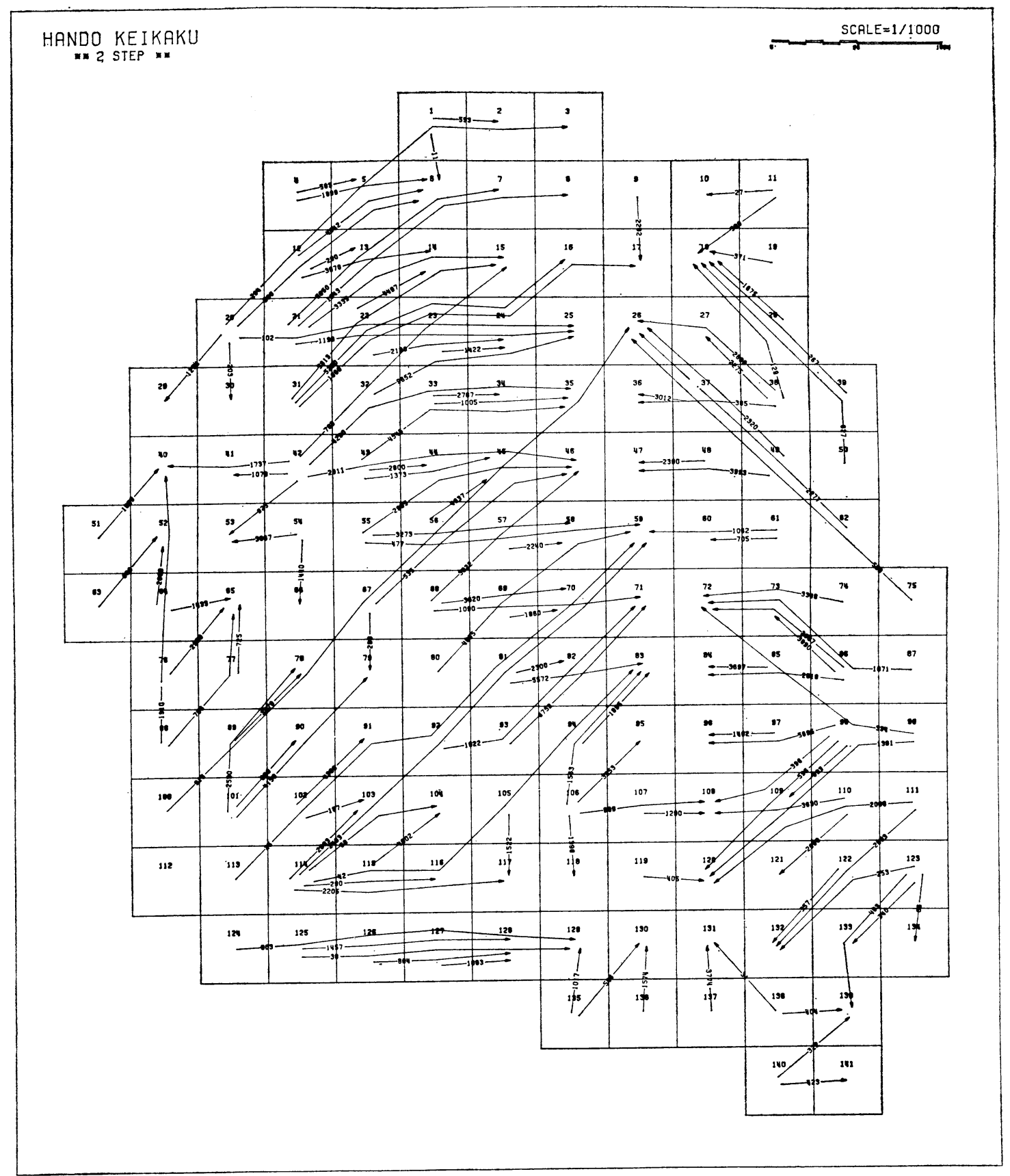

図一5搬土経路と運搬土量図

度の面からの制約も考慮する必要がある。たとえば, 30 万 $\mathrm{m}^{2}$ 程度の土地造成計画で, 200 ブロック ( 1 ブロ ック $40 \mathrm{~m} \times 40 \mathrm{~m})$ 程度に分割するとすれば, $500 \mathrm{~KB}$ 程 度の記憶容量が必要となる。一般にこの規模の計画で は, 最適解に到達するまでに 400 500 の代替案を比較 検討することになり，これらについて設計条件, 制約条 件を変えながら 5 6 通り比較するとすればかなりの処 理速度が要求される。たとえば前項の計算では, 電子計
算機として HITAC-8500（524 KB，サイクルタイム $0.84 \mu \mathrm{sec})$ と, 図化機として CALCOMP 915/1136 を 使用した場合, 200 ブロック程度の規模で 400 500 の 代替案が 10 分程度で処理される。

\section{（2）本システム利用上の留意点}

一般に，どの計画についても必要なことであるが，本 論文におけるように, 特に大量の計算を大型電子計算機 


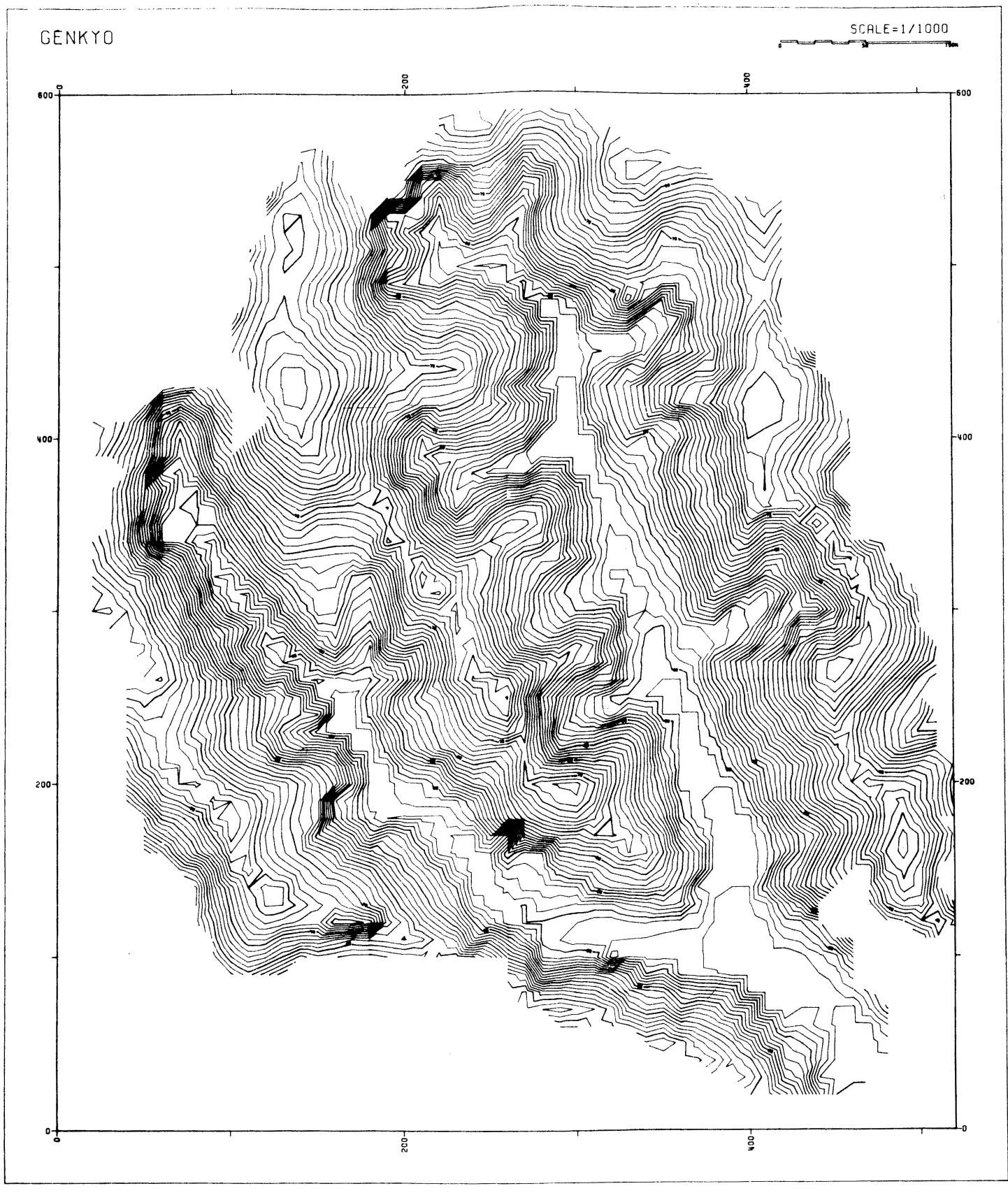

図一6 現 地形 図

で処理する場合には, 目的と目的達成のために要求され る精度を事前に明確にしておくことが重要である。たと えば， $m$ 個の切土ブロック上 $n$ 個の盛土ブロックがあ る場合, 初期解として $(m+n-1)$ 組の搬土計画ができ る。この解を改善するためには，

$$
\frac{(m \cdot n) !}{(m \cdot n-m-n+1) !(m+n-1) !}
$$

個の組合せを検討しなければならない。ちなみに， $m=$
$10, n=10$ とすれば $1.32 \times 10^{20}$ 個の組合せになる。さ いわい輸送問題では条件式, 目的関数がいずれも線型で あるので，おおよそ $(m+n)$ と同じオーダーの解の改善 で最適解に到達できるが，その場合でも膨大な計算量の 処理が必要であり，いかにすれば最も経済的に目的を達 成するかが重要な課題である。このシステムをより実情 に即して活用するには，重機に関するデータ，土質に関 するデータ, 施工法に関するデータなどのそれぞれにつ 


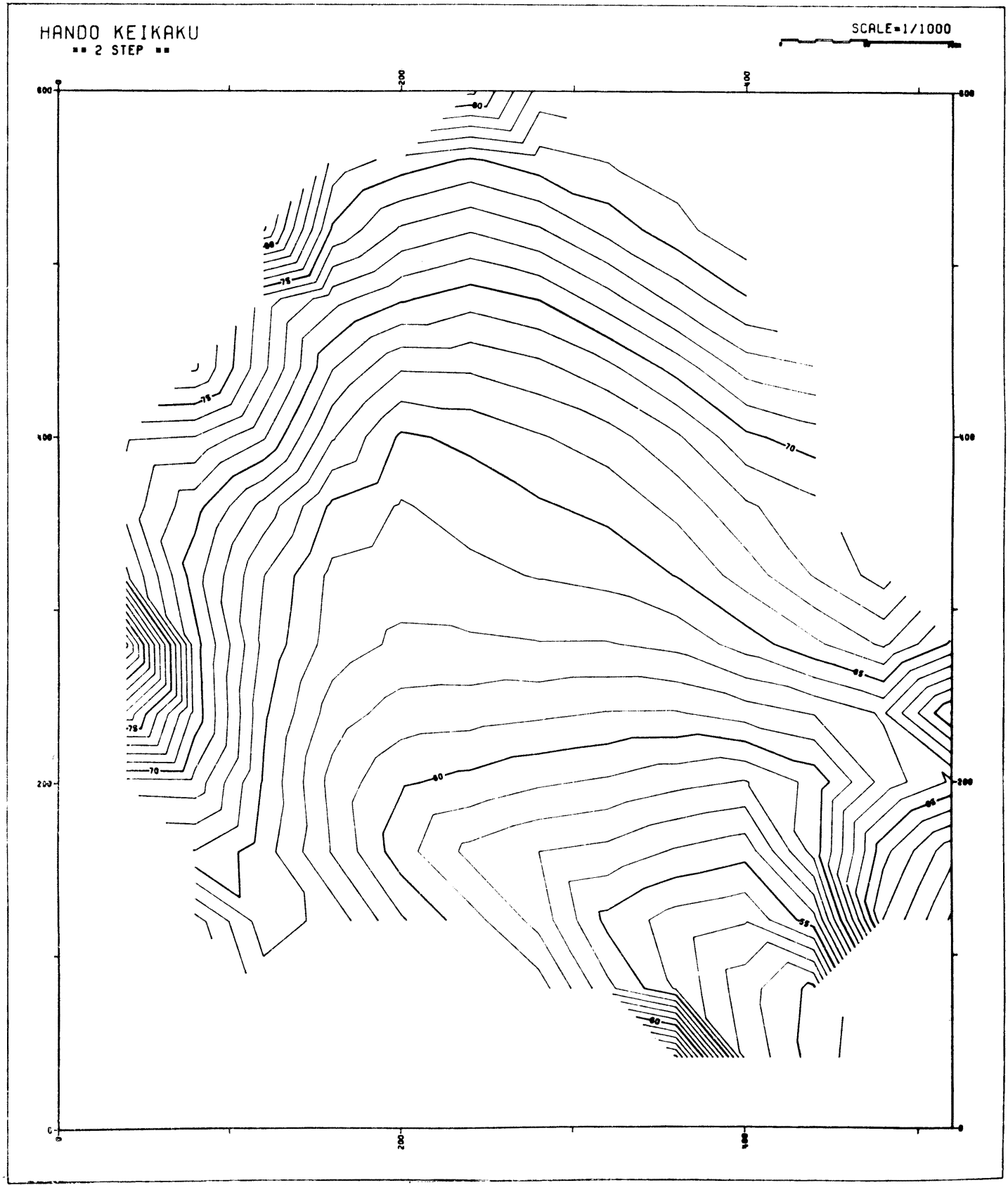

図一7 第 2 ステップ終了後の地形図

いて十分な吟味が必要である。重機に関するデータにつ いては，使用予定機種の性能とコストの特性をいかに的 確に表現するかが重要であり，このためには実績データ の活用や場合によっては現地試験等から有効な資料を得 ることも必要である。この時土質データと施工法の規定 は密接な関連において考慮する。たとえば,地盤が表土, 粘性土, 砂質土などの層状構造になっている場合, 各層 ごとに施工ステップを分割できれば，運搬土の有効な配
分, 妥当な土質データの賦与, その土質に最も適した機 種の準啃が可能となり, 搬土計画のレベルアップを図る ことができる。また，場外土取 (土捨) 場を含めて搬土 計画の最適化を図るには, 土取 (土捨) 場と施工区域の 間に土量 0 の仮想ブロックを考えて全体系についての最 適化問題を検討することが必要である。

急峻, 複雑な地形の地域で広大な土地造成計画の適切 なマスタープランを作成する作業は非常に困難で手間の 
かかる作業である。本システムに土量計算の機能を付加 すれば, 土量計算といら機械的な作業に要する労力を省 き，施工の段階までを含む経済性を検討することによっ て, マスタープランの評価, 修正といら作業サイクルが 迅速かつ容易に処理でき，計画，設計，施工のすべての 面にわたる一貫した最適化が可能になるであろう。

\section{5.おわりに}

目的関数を従来の作業量最小から工費最小纪換え, 地 形条件，施工法を考慮に入れて土工単価を求め，より現 実に即した計画へのレベルアップを意図した本研究は， この種の工事計画ならびに施工管理の面で少なからぬ改 善を果し得たと信じている。今後の方向としては, 定め られた施工計画をいかに忠実に実際の施工面で実現し， 計画と実施のよりよいバランスのもとに, 施工の過程で 得られた有益な実績資料を計画面へフィードバックさ
せ，さらに計画技法のレベルアップを図ることができる かにあると考えられる。

$$
\text { 参 考 文 献 }
$$

1）吉川ほか：整地工事に抢汀る機械稼動の解析，土木学会 第 26 回年次学術講演会講演集第 4 部, 1971.

2）春名・山本：造成工事化打引る機械系選定任関する一考 察, 土木学会第 27 回年次学術講演会講演集第 4 部, 1972.

3）春名・山本：大規模整地工事計画のシステム化に関する 研究, 土木学会論文報告集, 第 227 号, pp. 71 84, 1974.

4）村井：Elastic Surface Methodによる宅地造成設計の最 適化，土木学会論文報告集,第 214 号, pp. 37 46, 1973.

5）庄子・荒井：機械化土工に打ける工程計画管理最適化問 題の定式化, 土木学会論文報告集, 第 214 号, pp. 57 $70,1973$.

6）平田ほか：搬土計画 II，鹿島建設技術研究所 年報 第 19 号, 1970 .

7）日本建設機械化協会編：建設機械 と施工法，技報堂， 1966.

8）建設物価調查会編：建設工事標淮歩掛.

(1973.12.14 - 受付) 